\title{
THE INTERDISCIPLINARITY AND INNOVATIVENESS OF METHODS IN REHABILITATION OF CHILDREN WITH CEREBRAL PALSY
}

\author{
KAROLINA NOWAK \\ Faculty of Health Sciences, Wrocław Medical University, \\ Barta 5, 51-618 Wrocław \\ E-mail address: knowakk@vp.pl \\ MAGDALENA KAZIMIERSKA-ZAJĄC \\ Department of Disorders of the Nervous System, \\ Faculty of Health Sciences, Wrocław Medical University \\ Barta 5, 51-618 Wrocław \\ E-mail address: magdalena.kazimierska-zajac@umed.wroc.pl \\ LUBA JAKUBOWSKA \\ Department of Promotion of Health \\ Faculty of Health Sciences, Wrocław Medical University \\ Barta 5, 51-618 Wrocław \\ E-mail address: luba.jakubowska@umed.wroc.pl
}

\begin{abstract}
Thesis. Cerebral palsy $(\mathrm{CP})$ is a group of disorders resulting from damage to the central nervous system in the early stages of its development. The aim of the rehabilitation of persons with $\mathrm{CP}$ is to make their dependence on the assistance of others as little as possible and to improve their quality of life, as well as the quality of life of their families. New methods are developed in which new technologies are employed and a holistic approach to the patient, requiring the cooperation of specialists in various fields, is assumed.

The most commonly used methods of working with children with cerebral palsy include the NDT-Bobath method and the Vojta method. Apart from them, unconventional methods are also employed, including hippotherapy, virtual reality, the sensory integration method, the conductive education method, and the space suit method.

Aim of the paper. The aim of the paper is to present the methods employed in increasing the agility of children with cerebral palsy. Focus has been placed on traditional and commonly used methods, as well as the unconventional methods which are currently undergoing evaluation.
\end{abstract}


Results. Thanks to diversifying rehabilitation with new methods and enriching it with the experience of specialists in areas outside medicine, patients with cerebral palsy are able to fully benefit from their own potential. Quality of life is improved, independence is increased, and new opportunities are discovered. Some of the newest methods may serve to supplement traditional therapies, others can substitute for them in the future. What is crucial is to focus not only on heightening the physical agility of the patients, but also on making the course of the therapy more attractive, and on working on improving the patients' functioning in other areas of life, as well, such as social contacts or hobbies.

\section{INTRODUCTION}

Cerebral palsy $(\mathrm{CP})$ is a group of disorders resulting from damage to the central nervous system in the early stages of its development. The damage can take place in the mother's womb, during childbirth, or shortly after birth (Andruszczak, Buraczyńska-Andrzejewska \& Krauss, et al., 2012). Children with cerebral palsy are diagnosed with permanently impaired development of motor skills and posture as well as impaired sensory, cognitive, perceptive, and communication development, along with secondary skeletal and muscular problems (Michalska, Boksa, Wendorff \& Wiktor, 2012). Impaired speech, hearing, eyesight, intellectual disability, and epilepsy may constitute accompanying symptoms (Andruszczak, Buraczyńska-Andrzejewska \& Krauss, et al., 2012).

The frequency of the disorder globally oscillates between 1.4 and 3 in 1,000 children born alive. In Poland it is 2-2.5 in 1,000 children born alive (Makiełło-Jarży, 2013). Cerebral palsy is, therefore, the primary cause of physical disability and the second most common cause of neurodevelopmental disorders in children (Michalska, Boksa, Wendorff \& Wiktor, 2012). CP cannot be cured. Efforts need to be made, however, to alleviate the symptoms, to improve children's agility, and to increase their independence. In order to meet these aims, physiotherapeutic methods, medication, and surgery are employed (Rana, Rana, Upadhyay, et.al. 2017).

The main objective of the rehabilitation of children with CP is the minimalization of the effects of physical disability. Attempts are made to make the children as independent as possible, to improve their quality of life, as well as the quality of life of their families. Rehabilitation is focused on improvement of motor skills, allowing the children to fully use their own potential (Kerem-Günel, 2009). Before the introduction of therapeutic methods, a physiotherapist may decide to devote some time to the observation of the patient. It may allow the therapist to pinpoint the greatest problems in order to be able to concentrate on them, and to see what a child can already do unassisted. 


\section{METHODS EMPLOYED IN THE REHABILITATION OF CHILDREN WITH CEREBRAL PALSY}

\section{The NDT-Bobath method}

One of the methods used in the rehabilitation of children with cerebral palsy is the NDT-Bobath method (NDT - Neurodevelopmental Treatment). The method was developed by Bertha (a physiotherapist) and Karol (a neurologist) Bobath in the 1940s, and subsequently enhanced by Elizabeth Koeng (a paediatrician) and Mary Quinton (a physiotherapist) (Borkowska \& Szwiling, 2011). The Bobaths noticed that certain arrangements of the position of the body as well as properly conducted active and passive movements make it possible to alter the distribution of muscle tension (Pogorzelczyk \& Gajewska, 2014). The method has been undergoing development and modification on the basis of the progress in medicine and observation of the development of motor skills in children (Borkowska \& Szwiling, 2011). The concept of the NDT-Bobath method assumes that proper muscle tension is necessary for proper movements (Çömük Balc1, 2016). Improper muscle tension and surviving primitive reflexes lead the children with CP to incorrectly experience the position and the movements of their entire bodies or parts of their bodies, which facilitates the arising of incorrect models of movement. The first symptoms of impaired motor skills development are typically delayed raising of the head or inability to raise the head, and incorrect movement of the distal parts of the body that develop later in time and lead to the children assuming asymmetrical positions. A child's body is excessively straightened or bent (Borkowska \& Szwiling, 2011). In the method developed by the Bobaths specialist techniques are used to improve the impaired muscle tone and to strengthen the correct models of movement used in everyday life (Çömük Balc1, 2016).

During the sessions a therapist activates the entire body of a child, without limiting oneself to one part of the body only. That is how the body is being dynamically activated, and proper motor and sensory sensations are generated.

\section{The Vojta method}

The Vojta method relies on triggering reflexes by applying pressure to certain zones on the body (Steinborn, 2008). The pressure is applied by the therapist with their thumb, two fingers (middle and index finger) or the edge of the hand (Banaszek, 2010). The therapy assumes the activation of proper muscle groups necessary to carry out a particular motor function present in the model of global locomotion reflex (Dytrych, 2008). Achieving reflex reactions by applying pressure to correct areas of the body is greatly facilitated by placing a child in the activating position (Dytrych, 2008). It is the arrangement of the body that frequently causes children to be anxious and even cry during therapy sessions. These reactions are not caused by pain inflicted by the therapist, but by the uncomfortable, forced body position (Pogorzelczyk \& Gajewska, 2014). 
Improvement with the use of this method can be initiated even a few days after a child is born. It is at that moment that the central nervous system is at its highest flexibility, which increases the effectiveness of the rehabilitation (Pogorzelczyk \& Gajewska, 2014). It is the only physiotherapeutic method which does not require conscious motor activity of the child. The global influence of the Vojta method on the body additionally leads to improved sucking, swallowing, tongue functions, development of speech, and cessation of baby colic (Bagnowska \& Falkowski, 2013). The therapy ought to be conducted 3 to 4 times a day and, depending on the age and the needs of the child, last between a few and thirty minutes (Dytrych, 2008).

\section{Hippotherapy}

Apart from traditional methods used by physiotherapists increasingly often parents and specialists reach for methods which are not specific for improving children with $\mathrm{CP}$. They are used in therapies of other disorders, treatment of pain, improvement of social functioning, and in the general increase of the developmental potential of children and youth. One of these methods is hippotherapy, that is, all the therapeutic actions involving horses. It includes not only horse riding, but also the very contact between the patient and a horse, which leads to improved health and agility. The horse needs to be of a proper temperament: mild, trained, placid, and never skittish.

Hippotherapy improves the ability to hold the body upright (Long, 2014). Horse riding leads to enhanced body coordination, increases the ability to control the head and the torso, and improves patients' gait. The gait of the horse provides a precise, rhythmic, and repetitive movement model which closely resembles the mechanics of human gait. What is more, a horse's centre of gravity while walking is moved in a way which makes the horse's pelvis move in a way resembling the movements of a human pelvis. The rhythmic gait and the warmth of the horse allow hypertonic children to relax, and the strength of muscles and mobility of the joints are increased through adapting to the moves of the animal. Horse riding also boosts the sense of balance (Zadnikar \& Kastrin, 2011). The aforementioned rhythmic movements of the horse facilitate the secretion of adrenaline, which stimulates the vegetative system, leading to increased physical activity, improved mood, and concentration. Muscle tension, in turn, is decreased, the overall emotional stability is improved and neurotic reactions are weakened. Hippotherapy also allows social contacts to be improved. Children with CP often feel they are not fully accepted because of their illness, which is why in the centres where hippotherapy is conducted the instructors take care to allow disabled children to spend time with those without disabilities.

Hippotherapy can take on a number of forms, such as (Bednarczyk, 2015):

- Therapy with the movement of the horse exclusively - the patient does not move, depending only on the movement of the horse;

- Physiotherapeutic exercises during horse riding. The children not only depend on the movement of the horse, but are also activated during exercises led by a physiotherapist; 
- Maintaining emotional contact with the horse without sitting on it;

- A form of psychopedagogic horse riding which is conducted while seated on the horse or being next to it. It is aimed to facilitate intellectual, cognitive, emotional, and physical improvement.

In hippotherapy patients can spend time with horses by grooming, petting, and observing them. Thus children can learn to be responsible, they feel needed, and the proper fulfilment of duties boosts their self-esteem. Frequently spending time with these beautiful and majestic animals alleviates anxiety. Hippotherapy, thanks to the fact that it combines relation with a living creature and spending time outdoors is a sufficient supplement to other methods of the rehabilitation of children with CP (Bednarczyk, 2015).

\section{Therapeutic method with the use of virtual reality}

Virtual reality consists in using computer technology to present virtual, artificially generated sensory information in a way which allows experiencing them as if it were a part of the real world (Ravia, Singhiba \& Kumara, 2017). Therapy is conducted in a computer-simulated environment, which influences things and events in the real world, impacting eyesight, hearing, smell, and touch of the patients (Ravia, Singhiba \& Kumara, 2017). Taking into account the fact that computers and computer technology awaken children's interest, the method can be practical in the therapy of patients with CP (Snider, Darsak \& Majnemer, 2010).

The technologies used in virtual reality (VR) are numerous and greatly diverse. The devices used to transport the patient into VR range from uncomplicated and easy to use movement controls to advanced cameras with multiple movement sensors. To project the virtual world computer screens, TV screens, as well as VR helmets are used (Ravia, Singhiba \& Kumara, 2017).

Research results have demonstrated that the patients' engagement, necessary in this therapy, has positive influence on the reorganization of nerves, which appears to optimize the results of the rehabilitation of children with cerebral palsy. In children undergoing this therapy improvements of motor skills and agility are observed. Therapy with the use of virtual reality facilitates the acquisition of new motor skills, the maintenance of those previously acquired, and the transfer of those skills into the real world (Ravia, Singhiba \& Kumara, 2017). The main aim of the therapy is to increase confidence in motor exercises and getting patients engaged in actions based in playing which cannot be carried out in the real world (Snider, Darsak \& Majnemer, 2010). Research has also found that therapy with the use of VR improves:

- Patients' body posture;

- Ability to maintain balance;

- Control of the joints;

- Quality of gait;

- Upper limb functions (Ravia, Singhiba \& Kumara, 2017).

Currently, the employment of VR in therapy of children with CP is in the research stage. It cannot be with stated with utmost certainty that it is a good 
form of therapy just as it cannot be definitely stated that it has no beneficial influence on patients (Snider, Darsak \& Majnemer, 2010). In future the research on the method using VR in rehabilitation is to be broadened, conducted on a greater numbers of patients, in specially adapted space, and with the use of proper equipment (Ravia, Singhiba \& Kumara, 2017).

\section{Space suit method}

Yet another method employing technology is the space suit method.

In children with $\mathrm{CP}$, because of their neurological deficits, irreversible changes in the motor system take place. Independent compensation is not good, because it exacerbates the disfunction. That is why a therapist is needed who can direct the compensation in such a way as to maximally recreate the lost function. In directing the compensation it is practical to use a dynamic suit created on the basis of the functioning of space suits used by astronauts.

Space suit, also called a dynamic orthosis, consists of a vest and shorts of inflexible fabric. They are connected with plastic clasps. In order to make it possible to adjust the orthosis to a patient's body the vest and the shorts have vertical cuts on each side. Metal clasps are located symmetrically on both sides of the suit. Between the clasps rubber tie-rods are placed. Knee pads are also used. Depending on the fastening of the lower limb, they are fixed or moveable. To provide protection, fastening and stabilization pads, elastic bandages, and weights are employed. Elastic tie-rods, depending on the needs of the child, provide correction, support, supplementation, balance, or limitation. The tie-rods have a proprioceptive influence on the biomechanics of the patien$t^{\prime}$ s body. Thanks to the varied arrangement of the clasps, the elastic tie-rods can be placed in numerous configurations. They support the optimal position of the particular segments of the body (Małachowska-Sobieska, Demczuk-Włodarczyk, Wronecki, et.al., 2013).

Therapy with the use of such suits is based in the work of the suit against loads, improvement in patients' proprioceptive sensing, and correction of the position of the body. The space suit method is becoming increasingly popular because of its effectiveness, which is why objective actions ought to be undertaken in relation to this subject and accessibility of this form of therapy for children with cerebral palsy needs to be increased.

\section{Sensory integration method}

The following two methods are favoured by psychologists and pedagogues in the case of various disorders or in general positive influence on children. They are the sensory integration method and conductive education method (Peto).

Sensory integration is the process in which the nervous system receives information from the receptors of the senses of smell, taste, hearing, eyesight, touch, and the vestibular system. The information is interpreted and selected in order to be used to carry out premeditated actions and movements (Przyrowski, 2015). The sensory integration method was developed in the 1970s by A. 
Jean Ayres (Zimmer \& Desch, 2012). She had noticed that disorders of sensory integration lead to impaired development of muscle tension, posture, development of speech, cognitive functions, as well as impaired emotional development. Sensory integration therapy is contemporarily employed in working with children with psychomotor disorders.

Children with disorders of sensory processing are classified on the basis of how they react to external stimuli:

- Children avoiding sensory stimuli - sensory hypersensitivity. It consists of reacting to stimuli more powerfully than in the case of persons with correct sensory integration (Majchrzycki, Gajewska \& Łańczak-Trzaskowska, 2012). They perceive external stimuli in a sharper way, which is why the children avoid them, react too strongly to stimulation, they are afraid, they run from touch, they feel uncomfortable in crowded places, they react with high sensitivity to new smells (Radziyevska, Dziągwa \& Radziyevsky, 2012).

- Children reacting to stimuli with lower sensitivity - sensory hyposensitivity. Higher stimulation is required, stimulation of the child in order to achieve a sufficient level of stimulation from the environment. The behaviour of a child with sensory hyposensitivity is characterized by lack of focus, passiveness, absence. The child does not realize that it is dirty, does not pay attention to visual, olfactory, or audial stimuli. It is passive and does not want to play.

- Children requiring higher stimulation who provide this stimulation themselves - they enjoy powerful stimuli, they seek heightened sensory animation. Hugging them lightly is not enough, one needs to squeeze them hard to make them happy. What is beneficial to children seeking sensory stimuli is strong light, loud music, intensive smells. They require strong stimuli in all departments (Majchrzycki, Gajewska \& Łańczak-Trzaskowska, 2012).

Specialists working with the sensory integration method give the therapy the form of a science game. Its aim is to acquire the skill to properly react to external stimuli. The sessions are focused on, among others, stimulation of the sense of balance, which is formed through exercises on rails, stoops, swings, platforms, and ladders. The therapy concentrates on deep and superficial sensing, stimulation of the sense of eyesight, hearing, and smell. The level of the difficulty of the exercises depends on the skills of the child. The exercises ought to be conducted in a way that the child may complete them successfully. They must not be too easy or too difficult, and the level of difficulty ought to increase with the progress the child makes. Motivation and dedication are key, the therapist needs to motivate the child to be as engaged in the sessions as possible (Bagnowska \& Falkowski, 2013).

\section{Conductive education (Peto)}

The basis of the method of conductive education is a holistic approach to human beings. One ought to bear in mind that people develop not only physically, but also intellectually and socially. This assumption needs also to be 
made when working with children with disabilities. One should remember that children with $\mathrm{CP}$ have to learn everything in more complex conditions, and the learning does not come as easily as in the case of healthy children who are gifted with a natural capability to learn. Children with $\mathrm{CP}$ can arrive at the same results as healthy children as to the acquired knowledge; this requires, however, much more educational work, surpassing the efforts made by fully agile children (Grasza, 2010).

The educational system is based on the fundamental rules (F. Beck, in: Cytowska, 2016):

- The assumption that a child constitutes an entirety (physically, intellectually, and emotionally) which is placed within a process of constant change and development.

- Conductive education is a system undergoing constant change.

- Theories explaining conduct in the system of conductive education ought to be constantly updated.

Conductive education is to focus on that what a child can do, to take into account a child's learning capability and the acquisition of adaptation skills at a given point in time rather than concentrating on the problem of the individual and their correction. According to Peto, the aim of the method is a transition from disfunction to orthofunction (Cytowska, 2016). Coordination worse than proper or improper is perceived as a disfunction. Orthofunction is the ability to adapt to everyday life, the highest level of performing a task according to the abilities of a child, with the task performed independently and without pathological reactions and movements. The abilities of an individual child need to be taken into account, without making comparisons with others (Król, 2004).

The most important elements of conductive education are:

- Motivating a child to work.

- The intention of the mental state providing power to act.

- Learning through action, movement.

- The rule that human action is the result of learning through active participation.

- Social behaviour develops mainly thanks to observation and imitation.

- Full focus of emotions and motivation on a particular activity provides maximum energy to act.

- Learning takes place through direct experience and mediated learning (through a teacher, a therapist) (Cytowska, 2016).

Because of their needs, children with $\mathrm{CP}$ have to simultaneously learn the neuromotor functions such as movement, the self-help function, communication, and the intellectual function. Learning consists of perception of stimuli, their integration with previously acquired information, comparison, reply, and remembering. Motivation to learn is key, because to learn something a child must be willing and interested. Learning is based on the plasticity of the brain. Conductive education is a prolonged process of interaction between static damage and the dynamics of a developing plastic brain. 
Influence of the rehabilitative environment during therapy has enormous impact on the child's progress. The therapeutic team ought to present to the child an interesting rehabilitation plan, the atmosphere of the sessions has to be friendly, and the sessions need to be organised with a peer group. A child ought to have access to necessary equipment, help, and facilities. The therapist should make the sessions varied. Thanks to the repetition of a particular activity in various settings throughout the day a child remembers faster and more easily and consolidates the performance of an action, and, as a result, improves a function. A rehabilitation team leads the process of the learning of motor and cognitive functions, everyday life activities, social rules and behaviour and educational programme,

There are no ready programmes of working with children with the Peto method. The therapist is responsible for developing such a plan for a child. The sessions typically include establishing contact with peers and therapists, forming the ways of communicating on a level meeting the needs of the patient, developing major and fine motor skills, forming spatial orientation, developing a child's independence in the basic functions of everyday life, multisensory perception of the environment, forming the ability to work in a group, learning to work with a purpose on the basis of a child's interest, skills, and presented activity (Cytowska, 2016). The Peto method, because of its multilayer influence and addressing the complex needs of children with cerebral palsy is recognised as a model therapy of integrated rehabilitation, education, and social activities (Król, 2004).

\section{SUMMARY}

Children with CP cannot be cured, but they can be made more agile. That is why in spite of the high number of rehabilitation methods neither specialists nor parents will ever be fully satisfied with the results. Such approach and the development of knowledge and technology lead to the specialists constantly looking for new methods and conducting research on the effectiveness of the already existing ones (Nowotny, Czupryna \& Domagalska, 2009).

The paper only presents a part of the existing methods selected on the basis of their variedness.

The Vojta and NDT-Bobath methods are "classic" methods employed in physiotherapy. The former concentrates first and foremost on triggering proper reflexes, the latter on reducing muscle tension. The discomfort experienced by patients treated with the Vojta method leads to many discussions, which is why the parents/guardians ought to be informed that the child's aversion is not caused by pain but by the uncomfortable position assumed in the course of therapy. Nevertheless, the fact that the child does not feel well during the sessions may be reason enough to refuse participation.

In hippotherapy and the methods using virtual reality it is the comfort of the patient that constitutes the greatest value. The engagement of the patient in the rehabilitation, which is achieved by making the sessions interesting, is cru- 
cial to the effectiveness of the therapy. One ought to note, however, that these methods can be used with older children and they are, just like the space suit method, more costly than the "traditional" methods of physiotherapists. These methods are not specific to work with children with $\mathrm{CP}$, and their employment requires the engagement not only of physiotherapists and doctors, but also pedagogues, psychologists, and software developers.

In the rehabilitation of a child with $\mathrm{CP}$, just as with any other disability, one ought to remember not only to develop physical skills, but also to work on the quality of life of the patients in numerous areas, including the development of interests, participation in social life, and education, in the broad understanding of the word. That is why the methods used first and foremost by psychologists and pedagogues (including sensory integration and conductive education) may constitute valuable supplements to traditional rehabilitation. This understanding of rehabilitation is part of the broad idea of lifelong development.

\section{REFERENCES}

[1] Andruszczak B., Buraczyńska-Andrzejewska B., Krauss H., Jończyk-Potoczna K., Piątek J., Krzywicka A., Żukiewicz-Sobczak W., Krasowska E., \& Kozak M. (2012). Wielopłaszczyznowa opieka nad dzieckiem z mózgowym porażeniem dziecięcym [Multilayer care for children with cerebral palsy]. Medycyna Ogólna i Nauki o Zdrowiu 2012, 18 (4). 314-318.

[2] Bagnowska, K., Falkowski, M., (2013). Wybrane metody usprawniania dzieci z mózgowym porażeniem dziecięcym [Selected methods of developing the agility of children with cerebral palsy]. Nowa Pediatria, 3, 119-123.

[3] Banaszek, G. (2010). Metoda Vojty jako wczesna diagnostyka neurorozwojowa i koncepcja terapeutyczna [Vojta's method as the early neurodevelopmental diagnosis and therapy concept]. Przegląd Lekarski, 67(1), 67-76.

[4] Bednarczyk, M., (2015). Hipoterapia jako forma rehabilitacji i wsparcia włączania społecznego osób niepełnosprawnych [Hippotherapy as a form of rehabilitation and support of the social inclusion of persons with disabilities]. Student Niepetnosprawny. Szkice i Rozprawy, 15(8), 207-2017.

[5] Michalska, A., Boksa, E., Wendorff, J., Wiktor, P.J. (2012). Jakość życia dzieci i młodzieży z mózgowym porażeniem dziecięcym i niepetnosprawnościa intelektualna. Wybrane uwarunkowania spoteczno-demograficzne [Quality of life of children and youth with cerebral palsy and intellectual disabilities. Selected social and demographic conditions], Neurologia Dziecięca, 21 (42), 35-44.

[6] Borkowska, M., Szwiling, Z. (2011). Metoda NDT-Bobath. Poradnik dla rodziców [NDT-Bobath method. Guidebook for parents]. Warszawa: Wydawnictwo Lekarskie PZWL.

[7] Cömük Balc1, N. (2016). Current Rehabilitation Methods for Cerebral Palsy. Cerebral Palsy Mintaze Kerem Gunel, IntechOpen (pp.51-78). DOI: 10.5772/64373. Retrieved from: https:/ / www.intechopen.com/books/cerebral-palsy-current-steps/current-rehabilitation-methods-for-cerebral-palsy.

[8] Cytowska, B. (2016). Nauczanie kierowane jako metoda rozwijająca samodzielność oraz autonomię dzieci i młodzieży z głęboką niepełnosprawnością intelektualną [Conductive education as a method developing the independence and autonomy of children and youth with severe intellectual disability]. Interdyscyplinarne Konteksty Pedagogiki Specjalnej, 12, 61-83.

[9] Dytrych, G., (2008). Kontrowersje wokół metody Vojty - spojrzenie terapeuty [Controversy around the Vojta method - a view of a therapist]. Neurologia Dziecięca, 17 (33), 59-62.

[10] Grasza, J. (2010). Wyrównywanie szans edukacyjnych dzieci niepełnosprawnych w wieku od 210 roku życia poprzez zastosowanie metody nauczania kierowanego (Metoda Pëto) [Equalising the educational chances of disabled children aged 2-10 with the use of conductive education (Peto Method)]. Zeszyty Naukowe Wałbrzyskiej Wyższej Szkoły Zarzadzania i Przedsiębiorczości, 14 (1), 149-169.

[11] Król, M. (2004). Nauczanie kierowane jako system zintegrowanych dziatań rehabilitacyjno - edukacyjno - opiekuńczych wobec dzieci z wczesnym uszkodzeniem mózgu i ich rodzin [Conductive edu- 
cation as a system of integrated rehabilitation, education, and care actions for children with early brain damage and their families]. Zamość: Ośrodek Rehabilitacyjno-Terapeutyczny dla Dzieci Niepełnosprawnych w Zamościu.

[12] Long, S.A. (2014). Hippotherapy as a Tool for Improving Motor Skills, Postural Stability, and Self Confidence in Cerebral Palsy and Multiple Sclerosis. Sound Neuroscience: An Undergraduate Neuroscience Journal, 1 (1), 1-21.

[13] Kerem-Günel, M. (2009). Rehabilitation of children with cerebral palsy from a physiotherapist's perspective. Acta Orthopedica Traumatologica Turcica, 43(2), 173-180

[14] Majchrzycki, M., Gajewska, E., Łańczak-Trzaskowska, M. (Eds.) (2012). Dysfunkcje narzadów ruchu. Interdyscyplinarne rozumienie problemów zwiazanych z diagnostyka i terapia dziecka [Disfunctions of motor organs. Interdisciplinary understanding of the problems connected with the diagnosis and therapy of children]. Poznań: Uniwersytet Medyczny im. Karola Marcinkowskiego w Poznaniu.

[15] Makiełło-Jarży, G., (2013). Ból i cierpienie [Pain and suffering]. Kraków: Acta Academiae Modrevianae.

[16] Małachowska-Sobieska, M., Demczuk-Włodarczyk, E., Wronecki, K., Skolimowski, T., Kwiatkowski, R., Skolimowska, B., Staniszewski, Ł. (2013). Ocena oddziaływania ortezy dynamicznej „Dunag 02” na mięśnie kończyn dolnych w czasie chodu dziecka z hipotonią i bezładem ruchowym [Assessment of the influence of the dynamic orthosis "Dunag 02" on the muscles of lower limbs in the gait of a child with hypotony and motor anomy]. Fizjoterapia, 21, 4, 50-62. doi: 10.2478/ physio-2013-0046

[17] Nowotny, J., Czupryna, K., Domagalska, M. (2009). Aktualne podejście do rehabilitacji dzieci z mózgowym porażeniem dziecięcym [Current approach to rehabilitation of cerebral palsied children]. Neurologia Dziecięca, 18, 35, 53-60.

[18] Pogorzelczyk, M., Gajewska, E. (2014). Terapia dziecka z mózgowym porażeniem dziecięcym z punktu widzenia fizjoterapeuty [Therapy of a child with cerebral palsy from the point of view of a physiotherapist]. Polski Przeglad Nauk o Zdrowiu, 1 (38), 43-47.

[19] Przyrowski, Z. (2015). Kliniczna Obserwacja [Clinical observation]. Warszawa: Empis. Warszawa.

[20] Radziyevska, M., Dziągwa, E., Radziyevsky, P. (2012). Zaburzenia integracji sensorycznej wśród dzieci i młodzieży [Disorders of sensory integration in children and youth]. Pedagogika, psychologia i medyczno -biologiczne problemy wychowania fizycznego i sportu, 4, 135-40.

[21] Rana, M., Upadhyay, J., Rana, A., Durgapal, S., Jantwal, A. (2017). A Systematic Review on Etiology, Epidemiology, and Treatment of Cerebral Palsy. International Journal Of Nutrition, Pharmacology, Neurological Diseases, 7(4), 76-83. doi:10.4103/ijnpnd.ijnpnd_26_17

[22] Ravi, D. K., Kumar, N., Singhi, P. (2017). Effectiveness of virtual reality rehabilitation for children and adolescents with cerebral palsy: an updated evidence-based systematic review. Physiotherapy, 103(3), 245-258. doi:10.1016/j.physio.2016.08.004

[23] Snider, L., Majnemer, A., Darsaklis, V. (2010). Virtual reality as a therapeutic modality for children with cerebral palsy. Developmental Neurorehabilitation, 13(2), 120-128. doi:10.3109/17518420903357753

[24] Steinborn, B., (2008). Wybrane zagadnienia z neurologii dziecięcej: padaczka wieku rozwojowego i mózgowe porażenie dziecięce - możliwości diagnostyczne i lecznicze [Selected problems of child neurology: epilepsy of the development age and cerebral palsy - opportunities of diagnosis and treatment]. Family Medicine \& Primary Care Review, 10 (1), 107-115.

[25] Szymczak, M. (2009). Wpływ zajęć hipoterapeutycznych na rozwój dzieci z mózgowym porażeniem dziecięcym [The influence of hypotherapeutic activities on the development of children with infantile cerebral palsy]. Pielegniarstwo Polskie, 4(34), 282-285,

[26] Zadnikar, M., Kastrin, A. (2011). Effects of hippotherapy and therapeutic horseback riding on postural control or balance in children with cerebral palsy: a meta-analysis. Developmental Medicine And Child Neurology, 53(8), 684-691. doi:10.1111/j.1469-8749.2011.03951.x

[27] Zimmer, M., Desch, L. (2012). Sensory integration therapies for children with developmental and behavioral disorders. Pediatrics, 129(6), 1186-1189. doi:10.1542/peds.2012-0876 